JEL Classification: E500

\title{
ЗАСТОСУВАННЯ ЕКОНОМІКО-МАТЕМАТИЧНИХ МЕТОДІВ ПРОГНОЗУВАННЯ ЯК ШЛЯХ УДОСКОНАЛЕННЯ СИСТЕМИ БАНКІВСЬКОГО КРЕДИТУВАННЯ
}

\section{Прокопенко М.В., стариий викладач \\ Харківський національний автомобільно-дорожній університет;}

Постановка проблеми. Кредитна політика - це стратегія й тактика банку в області кредитних операцій. Не існує єдиної кредитної політики для усіх банків. Кожен банк формує свою власну кредитну політику, з урахуванням економічних, політичних, географічних, організаційних та інших факторів які впливають на його діяльність. Вважається що ризики банку підвищуються якщо він не має своєї кредитної політики; якщо банк iï має, але не довів до відома всіх виконавців; якщо він має суперечливу або неконкретну політику.

В закордонній банківській практиці формування кредитної політики включає по-перше визначення стратегії, затверджуваної радою директорів (правлінням); по-друге розробку докладного посібника зі здійснення кредитних операцій, покликаного забезпечити реалізацію стратегічних напрямків діяльності банку в даній сфері за допомогою сучасних методів.

Зазначеним вище доводиться актуальність проблеми та необхідність докладного дослідження кредитування в сучасних умовах.

Аналіз останніх досліджень і публікацій. Проблемі пов'язаній зі створенням ефективної кредитної політики банку присвячена велика кількість досліджень вітчизняних та зарубіжних авторів.

Вагомий внесок в дану проблематику внесли такі вчені як А. Маршалл, Л. Вальрас, Д Робинсон.

Також необхідно виділити таких вітчизняних вчених як О. Васюренко [1], К. Волохата [1], А. Мороз [2], Л. Кузнєцова [3], С. Ревенчук [4], та ін.

Вищеперераховані вчені визначають кредит як надання грошей або товарів у борг, як правило зі сплатою відсотків що $є$ вартісною економічною категорією, невід'ємним елементом товарно-грошових відносин. Банківське кредитування здійснюється при строгому дотриманні певних принципів які $\epsilon$ головним елементом системи кредитування, оскільки відображають сутність зміст кредиту.

До основних принципів кредитування вчені відносять:

- зворотність - обов’язкова виплата кредиторові суми основного боргу на певних умовах; ця особливість відрізняє кредит від інших економічних категорій товарно-грошових відносин;

- терміновість - заздалегідь визначені строки повернення кредиторові позикових коштів, тобто часова визначеність повернення кредиту, порушення 
якої спричиняє застосування певних санкцій. Строк кредитування є граничним часом знаходження позичкових коштів у розпорядженні позичальника.

В сучасних умовах економічної кризи та після вивчення і критичного осмислення наукової літератури автор відносить до сучасних основних принципів кредитування також диференційованість, платність та забезпечення.

Диференційованість - означає що банки не повинні однозначно підходити до питанню про видачу кредиту своїм клієнтам, що претендують на його одержання. Кредит повинен надаватися тільки тим клієнтам, які в змозі вчасно його повернути. Диференціація кредитування повинна здійснюватися на основі показників кредитоспроможності, під якими розуміється фінансовий стан позичальника, що дає впевненість у здатності й готовності його повернути кредит в обумовлений договором строк. Диференційованість кредитування, виходячи із кредитоспроможності позичальників, перешкоджає покриттю їхніх втрат і збитків за рахунок кредиту й служить необхідною умовою його нормального функціонування на основах зворотності й платності.

Платність - грунтується на відплатному характері послуг, надаваних банками при кредитуванні. За надання банківської позички, як правило, стягується певна плата у вигляді відсотків. Розмір процентної ставки встановлюється сторонами за кредитним договором.

Забезпечення - це спосіб повернення банківського кредиту, що може бути реалізований за допомогою застави, банківських гарантій, страхування й інших способів, передбачених законодавством і договором між партнерами.

Донедавна ці принцип кредитування трактувалися економістами дуже вузько, сучасні методики математичного моделювання для їх дослідження та розробки рекомендацій широко не використовувалися.

Невирішені складові загальної проблеми. Для прийняття банком рішень на вибір власних цілей у сфері кредитування важливе значення мають:

- постановка загальних цілей діяльності банку на майбутній період, зокрема відносно прибутковості й ліквідності;

- адекватний аналіз кредитного ринку (попиту та пропозиції кредитних послуг), включаючи відносини централізованих кредитних ресурсів до загальної маси кредитних вкладень по країні в цілому або регіону;

- ясність перспектив розвитку ресурсної бази банку;

- вірна оцінка якості свого кредитного портфеля.

Але при прийнятті таких рішень економетричні методи, структурний аналіз, економіко-математична формалізація, метод коефіцієнтів, регресійне моделювання майже не використовується що призводить до негативних наслідків.

Формування цілей статті. Мета дослідження полягає в розробці шляхів підвищення ефективності прийняття управлінських кредитно - банківських рішень за допомогою розробки прикладу кореляційно-регресійної моделі оптимізації позичкового відсотка по кредитним операція банку за критерієм максимального прибутку. 
Виклад основного матеріалу дослідження. Для ефективної й прибуткової роботи комерційного банку основне значення має наскільки банк правильно й виважено підходить до вибору напрямків кредитної політики.

Процес удосконалення кредитної політики потрібно розглядати в комплексі, а не окремо, тому що від того наскільки правильно банк буде поводитися при формуванні депозитного портфеля, настільки ефективною і прибутковою буде його кредитна політика.

Одним $з$ основних напрямків удосконалення кредитної політики банку $є$ ефективне використання сучасних економіко - математичних методів.

Банківським фахівцям необхідно знати й постійно аналізувати їх фінансово-господарську поточну діяльність, прогнозувати тенденції ï зміни. Для цього в кожному банку доцільно створювати інформаційну систему й використовувати ці дані для аналізу. Цим можуть займатися співробітники спеціальних аналітичних підрозділів.

Саме незнання характеру й особливостей сучасних математичних методів, невміння працювати 3 ними в умовах загострення ситуації на кредитному ринку не дозволяє банкам ефективно взаємодіяти 3 клієнтами. Особливо важливі питання виникають при видачі кредиту, тому що від того на скільки точною i повною буде інформація про позичальника, залежить подальше співробітництво банку з клієнтом (чи зможе позичальник погасити суму боргу й відсотки за користування кредитом у встановлений договором строк).

Також це важливо для залучення клієнтів інших банків для розширення обсягів кредитування. Тут клієнтам потрібно пропонувати вигідні й привабливі для них кредитні проєкти - але обгрунтовані математично.

Кредитна діяльність будь-якої банківської організації завжди пов'язана 3 ризиком тому що постійно існує ймовірність порушення позичальником строків погашення кредитів, несплати відсотків і так далі. Багато факторів впливає на величину ризику й імовірності його настання, адже клієнти банків здійснюють свою діяльність у специфічних галузях, мають різний технічний і фінансовий стан, перспективи розвитку своєї діяльності. Тому у сформованих умовах банківським фахівцям просто необхідно правильно оцінювати й мінімізувати ризики [5].

При формуванні кредитно-депозитної політики банку потрібно враховувати три види ризику:

a) кредитний ризик - це ризик несплати позичальником основного боргу й відсотків або недотримання контрактів умов кредитної угоди відповідно до прийнятого на себе зобов'язаннями;

б) ризик ліквідності - це ризик, при якому в банку недостатньо коштів для виконання своїх зобов'язань перед клієнтами у встановлений термін;

в) процентний ризик - ризик зниження процентної ставки, що негативно впливає на прибутковість банку [6].

Вірогідність та розмір кожного $з$ представлених видів ризику можна спрогнозувати за допомогою сучасних математико - економетричних методів. 
Наступним етапом зниження кредитного ризику $\epsilon$ попередній статистичний аналіз кредитоспроможності позичальника. Саме на основі кредитоспроможності позичальника встановлюються основні положення кредитного договору й приймається рішення про видачу позики. В умовах конкуренції позиції банків будуть у більшій мері залежить від обгрунтованості кредитної політики банку. В англомовній літературі розроблені й використовуються на практиці сім принципів раціонального кредитування, які визначаються абревіатурою CAMPARI, що створена 3 початкових букв таких слів:

$\mathrm{C}$ - character - характеристика позичальника (його особисті якості);

A - ability - здатність клієнта повернути позику;

M - margin - маржа (прибутковість) кредитної операції;

$\mathrm{P}$ - purpose - ціль заради якої береться позика;

A - amount - сума кредиту;

$\mathrm{R}$ - return - умови повернення кредиту;

I - insurance - страхування ризику неповернення кредиту [7].

Кожен з цих принципів реалізовано у спеціальних програмних засобах, побудованих на засадах економіко - математичного прогнозування.

Для розрахунку ефективності заходів оптимізації кредитно-депозитної політики проведемо кореляційно-регресійний аналіз для визначення тісноти зв'язку між притягнутими та розміщеними коштами й відповідними процентними ставками по них.

Отримана плата за кредити є основною частиною одержуваних банком доходів, а оплата банком депозитів - основною частиною видатків. Тому дуже важливо вивчити залежність процентної ставки від ряду зовнішніх і внутрішніх факторів, а також вплив ставки на них.

Рівень процентної ставки залежить від наступних факторів:

- рівень інфляції в країні;

- ставка рефінансування Національного банку, що грає роль офіційної «ціни грошей» на кредитному ринку;

- середня процентна ставка по міжбанківському кредиту;

- ставка LIBOR (для кредитування у валюті);

- середня процентна ставка в банку по депозитах;

- структура кредитних ресурсів банку (чим вище частка дорогих ресурсів у пасиві банку, тим дорожче видаваний кредит);

- попит на кредит, що пов'язаний з настроєм інвесторів щодо вкладень у реальний сектор економіки, рівнем прибутковості інших способів інвестування (наприклад, вкладення у валюту, цінні папери);

- призначення й умови кредиту, ступінь ризику;

- операційні видатки й доходи банку [8].

Тому доцільно буде проаналізувати й вивчити тісноту залежності середньої процентної ставки за користування кредитом і обсягів виданих кредитів, а також залежність процентної ставки по кредитах від середньої процентної ставки по депозитах. 
Для цього використовуємо методи економічного аналізу. Найбільш широке застосування в економічному дослідженні знайшли прийоми кореляційно-регресійного аналізу які дозволять кількісно виразити взаємозв'язок між показниками [9].

Кореляційний зв'язок - це неповна, імовірнісна залежність між показниками, що проявляється тільки в спостереженнях.

Необхідні умови для застосування кореляційного аналізу:

а) наявність досить великої кількості спостережень про величину досліджуваного фактору й результативних показників (у динаміці або за поточний рік у сукупності однорідних обсягів).

б) досліджувані фактори повинні мати кількісний вимір і відображатися в тих або інших джерелах інформації [10].

Прийоми кореляційно-регресійного аналізу дозволяють вирішити наступне завдання: визначити зміну результативного показника під впливом одного або декількох факторів (в абсолютному вираженні), тобто визначити на скільки одиниць зміниться величина результативного показника від кожного фактору.

Для аналізу скористаємося гіпотетично достовірними випадковими даними, які подано в таблиці 1 .

Таблиия 1

Ефективність притягнутих і розміщених коштів

\begin{tabular}{|l|r|r|r|c|c|}
\hline \multirow{2}{*}{ Статті аналізу } & \multicolumn{2}{|c|}{ Абсолютні показники, т.грн. } & \multicolumn{2}{c|}{ Темп приросту, \% } \\
\cline { 2 - 6 } & \multicolumn{1}{|c|}{2018} & \multicolumn{1}{c|}{2019} & \multicolumn{1}{c|}{2020} & $2018-2019$ & $2019-2020$ \\
\hline Притягнуті кошти & 62354,0 & 71144,0 & 86871,4 & 14,09 & 22,10 \\
\hline Розміщені кошти & 37062,5 & 42982,6 & 52393,3 & 15,97 & 21,89 \\
\hline Сальдо коштів & $-25291,5$ & $-28161,4$ & $-34478,1$ & 11,34 & 22,43 \\
\hline Процентні видатки & 4508,11 & 6251,11 & 8268,23 & 38,66 & 32,26 \\
\hline Процентні доходи & 12515,06 & 13985,52 & 17097,57 & 11,74 & 22,25 \\
\hline Процентний прибуток & 8006,95 & 7734,41 & 8829,34 & $-3,40$ & 14,15 \\
\hline $\begin{array}{l}\text { Середній відсоток по } \\
\text { притягнутим коштам, \% }\end{array}$ & 7,22 & 8,786 & 9,51 & 21,53 & 8,32 \\
\hline $\begin{array}{l}\text { Середній відсоток по } \\
\text { розміщеним коштам, \% }\end{array}$ & 33,76 & 32,53 & 32,63 & $-3,64$ & 0,29 \\
\hline
\end{tabular}

Джерело: розраховано за гіпотетично достовірними випадковими даними

Розрахунок проведемо за допомогою програми EXCEL. На рисунках 1 i 2 показані лінії тренду, що відбивають динаміку й зв'язок між аналізованими показниками. 


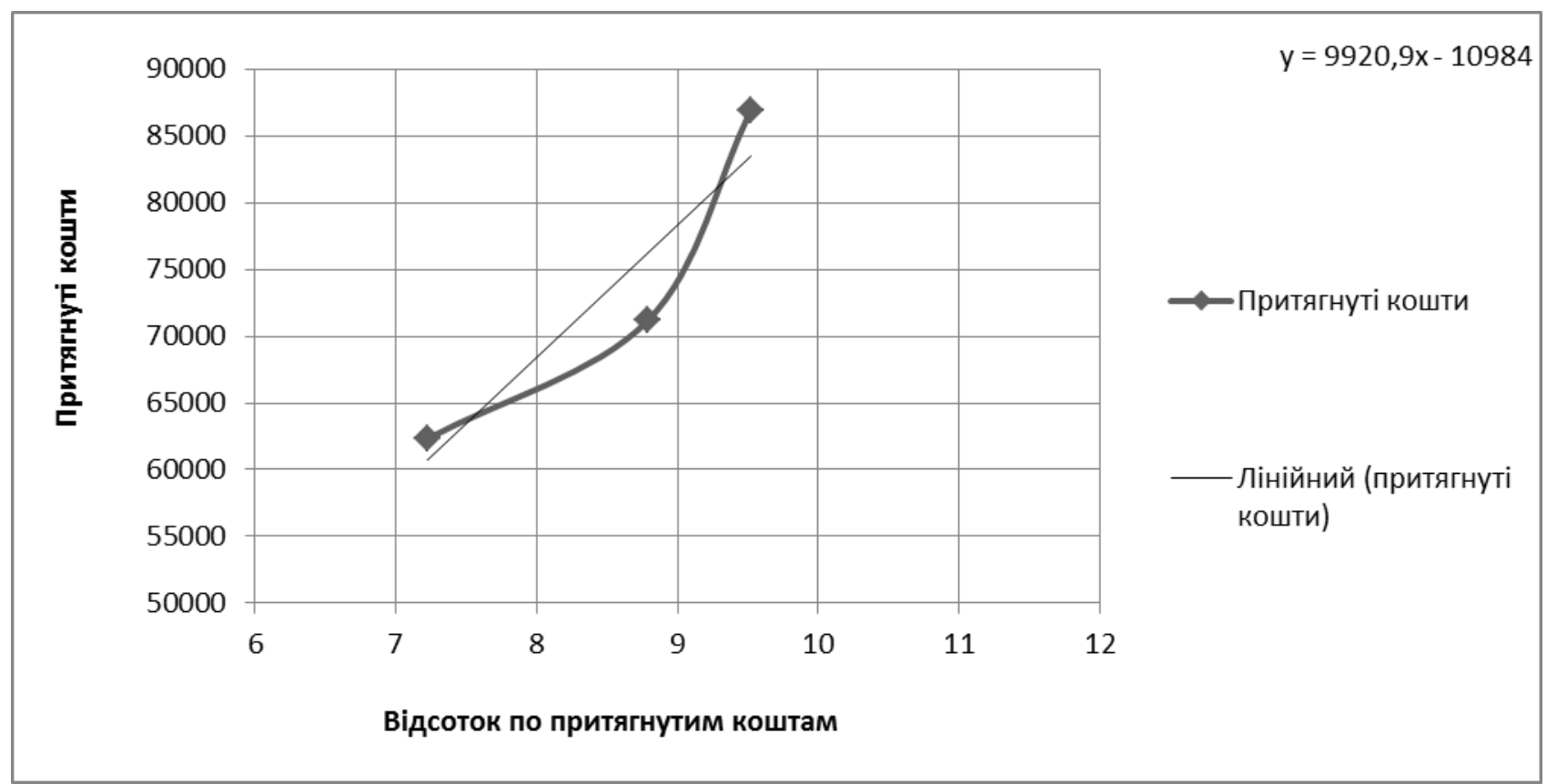

Рис. 1. Динаміка притягнутих коштів даними

Джерело: розраховано за гіпотетично достовірними випадковими

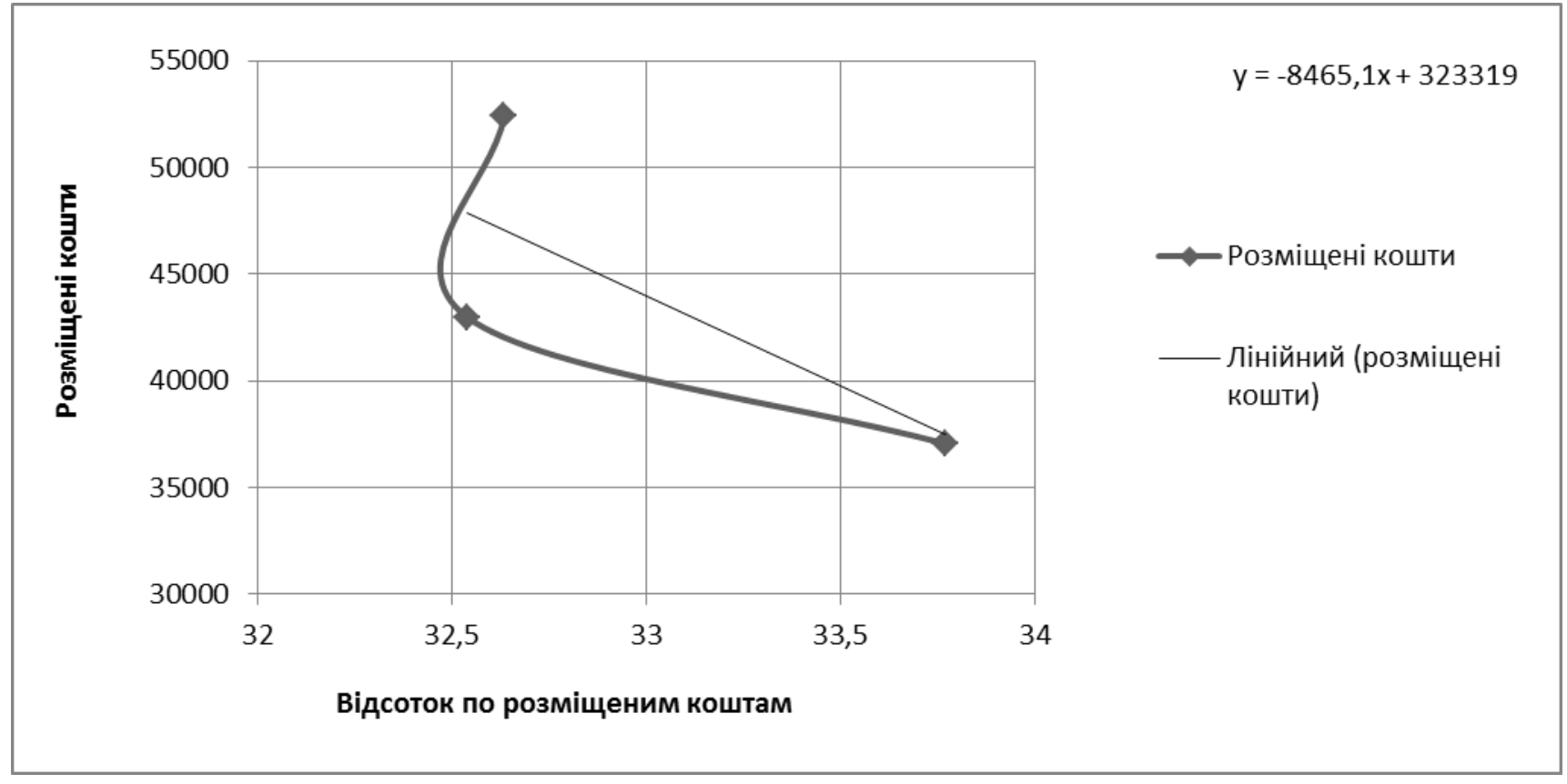

Рис. 2. Динаміка розміщених коштів

Джерело: розраховано за гіпотетично достовірними випадковими даними

Рівняння регресії описуються простими лінійними рівняннями:

$$
\text { в }=-10984+9920,9 x \text { - для притягнутих коштів; }
$$




$$
\text { в }=323319-8465,1 \mathrm{x}-\text { для розміщених коштів, }
$$

де $\quad$ в - обсяг коштів, т. грн.

x - величина відповідно банківського й позичкового відсотків.

Дохід від розміщених коштів можна визначити як добуток об'єму коштів на рівень позичкового відсотка:

$$
\mathrm{TR}=\mathrm{y} * \mathrm{x}
$$

а з урахуванням рівняння регресії:

$$
\mathrm{TR}=(323319-8465,1 \mathrm{x}) * \mathrm{x} / 100=3233,19 \mathrm{x}-84,651 \mathrm{x}^{2} .
$$

Завданням кредитної політики є максимізація обсягу розміщених коштів, тобто для рішення поставленої проблеми необхідно знайти максимум функції TR. Для цього візьмемо похідну від функції й одержимо граничний дохід від розміщених коштів.

$$
\mathrm{MR}=\mathrm{TR}^{\prime}=323319-2 * 8465,1 \mathrm{x}=3233,19-169,302 \mathrm{x} .
$$

Оптимальне значення ставки позичкового відсотка визначиться:

$$
\begin{gathered}
\mathrm{MR}=0 \\
3233,19-169,302 \mathrm{x}=0 \\
\mathrm{x}=19,09 \% .
\end{gathered}
$$

Таким чином, при позичковому відсотку 19,09\% банк розмістить максимальну кількість коштів.

Граничний розмір розміщених коштів обмежується максимальним розміром позикових коштів. Визначимо максимальний прогнозний обсяг кредитів.

Отримані дані мають приблизне значення, що пояснюється наближеністю побудованої математичної моделі й малою кількістю даних для розрахунку рівняння регресії.

Результати прогнозування відіб'ємо на рисунку 3. 


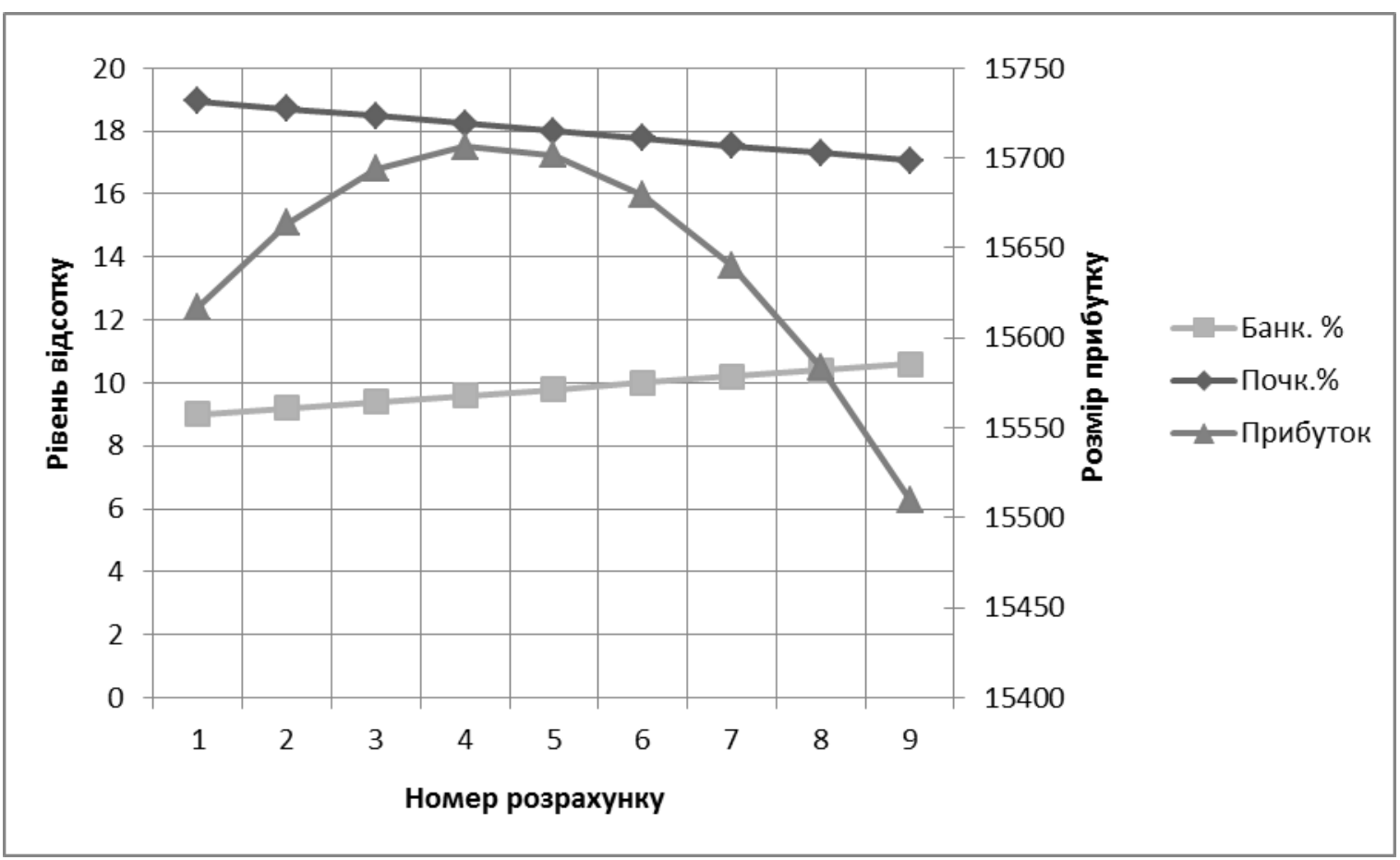

Рис. 3. Прогноз процентного прибутку комерційного банку даними

Джерело: розраховано за гіпотетично достовірними випадковими

Таким чином можна констатувати, що розроблена кредитно-депозитна політика $є$ найбільш ефективною й забезпечує приріст процентного прибутку банку.

Висновки 3 проведеного дослідження. В умовах жорсткої банківської конкуренції все більше значення для удосконаленні роботи банків у напрямку кредитної політики мають методи математично-маркетингового дослідження усіх аспектів кредитування, тобто співробітництво зі спеціалізованими фірмами або створення власних аналітичних відділів.

Взагалі доцільно було б для кожного комерційного банку залучити до співробітництва як партнерів аналітично-маркетингову фірму та спеціалізовану страхову компанію.

В сучасних умовах без аналізу поточної кон’юнктури ринку й тенденцій змін на ньому, без уміння розраховувати математично обгрунтовану прибутковість проєктів реалізованих у вигляді кредитів, дати кваліфіковану консультацію неможливо як і очікувати беззбиткову кредитну діяльність.

Без сумніву, недоцінка банком значення сучасних методів математичного прогнозування не сприяє зростанню прибутку банку. Це не дозволяє багатьом банкам правильно оцінити ефективність своїх кредитних проєктів і тим самим забезпечити повернення позик і відсотків по ньому.

Зниження збитковості кредитної діяльності в значній мірі залежить від точного аналізу та математико-економічного обгрунтування кредитного проєкту, контролем за цільовим використанням кредиту з боку банківських фахівців. 
Однак, у цей час у сфері банківського підприємництва працює велика кількість непідготовлених людей, це призвело до того що більшість із них не можуть кваліфіковано скласти математико-економічне обгрунтування проєкту кредитування, точно розрахувати період його окупності, інші важливі характеристики. Часто математико-економічне обгрунтування не подається взагалі або ж несе недостовірну інформацію.

Без такого обгрунтування проєкту кредитування або ефективне його складання неможливо, тому вкрай необхідно здійснити контроль за прогнозностатистичним використанням коштів, вчасно вжити необхідних заходів по недопущенню збитків (мінімізації) та підвищенню рівня прибутку.

\section{Перелік посилань}

1. Васюренко О. В., Волохата К. О. Економічний аналіз діяльності комерційних банків. навч. посібник. К.: Знання, 2016. 464 с.

2. Мороз А. М. Банківські операції. К.: КНЕУ, 2015. 608 с.

3. Кузнєцова Л. В. Роль банківського кредитування у фінансовому забезпеченні розвитку реального сектору економіки України. Економічний nростір. 2008. №20/1. C. 107-115.

4. Ревенчук С. К. Гроші та кредит. К.: Знання, 2014. 382 с.

5. Солоділова К. В., Шафранова О. В. Сучасний стан кредитування в Україні. Молодий вчений. 2017. № 3(43). С. 844-847.

6. Жукова Н. К., Зражевська Н. В. Сучасний стан ринку банківських кредитів в Україні. Економічний часопис. XXI. 2011. № 5-6. С. 54-57.

7. Барановський О. І. Розвиток банківської системи України: монографія. Київ, Ін-т екон. та прогнозув., 2008. 584c.

8. Барановський О. І. Фінансові кризи: передумови, наслідки і шляхи запобігання: монографія. Київ. Нац. торг.-екон. ун-т, 2009. 754 с.

9. Сергєєва О. С., Тищенко М. О. Проблеми кредитної діяльності банківської системи України. Східна Свропа: економіка, бізнес та управління. 2017. № 3(08). С. 317-321.

10. Вітлінський В. В. Аналіз, моделювання та управління економічним ризиком. Київ: КНЕУ, 2016. 292 с.

\section{References}

1. Vasyurenko, O. V., Voloxata, K. O. (2016), The Economic analysis of activity of commercial banks [Ekonomichnyi analiz diialnosti komertsiinykh bankiv: navch. posib.], Knowledge, Kyiv, 464 p. $608 \mathrm{p}$.

2. Moroz, A. M. (2015), Bank transactions [Bankivski operatsii], KNEУ, Kyiv,

3. Kyznecova, L. V. (2008), Role of the bank crediting in the financial providing of development real to the sector of economy of Ukraine [Rol bankivskoho kredytuvannia u finansovomu zabezpechenni rozvytku realnoho sektoru ekonomiky Ukrainy], Economic space, No 20/1, P. 107-115.

4. Revenchuk, C. K. (2014), Money and credit [Hroshi ta kredyt], Knowledge, Kyiv, 382 p. 
5. Solodilova, K. V., Shafranova, O. V. (2017), Modern state of crediting in Ukraine [Suchasnyi stan kredytuvannia v Ukraini], Young scientist, No 3 (43), P. 844-847

6. Zhukova, H. K., Zrajevska, N. V. (2011), Modern market of bank credits condition in Ukraine [Suchasnyi stan rynku bankivskykh kredytiv $\mathrm{v}$ Ukraini], Economic magazine, No 5-6, P. 54-55.

7. Baranovsky, O. I. (2008), Development the banking system of Ukraine: monograph [Rozvytok bankivskoi systemy Ukrainy: monohrafiia], IEP, Kyiv, 584 p.

8. Baranovsky, O. I. (2009), Financial crises: pre-conditions, consequences and ways of prevention: monograph [Finansovi kryzy: peredumovy, naslidky i shliakhy zapobihannia: monohrafiia], NTEY, Kyiv, 754 p.

9. Sergeeva, O. S., Tishenko, M. O. (2017), Problems of credit activity of the banking system of Ukraine [Problemy kredytnoi diialnosti bankivskoi systemy Ukrainy], East Europa: economy, business and management, No 3(08), P. 317-321.

10. Vitlinskiy, V. V. (2016), Analysis, modeling and management of economic risk [Analiz, modeliuvannia ta upravlinnia ekonomichnym ryzykom], KNEУ, Kyiv, $292 \mathrm{p}$.

\section{РЕФЕРАТИ РЕФЕРАТЫ ABSTRACTS}

\section{УДК 336.71; JEL Classification: Q500 \\ Прокопенко М.В. ЗАСТОСУВАННЯ ЕКОНОМІКО- МАТЕМАТИЧНИХ МЕТОДІВ ПРОГНОЗУВАННЯ ЯК ШЛЯХ УДОСКОНАЛЕННЯ СИСТЕМИ БАНКІВСЬКОГО КРЕДИТУВАННЯ}

Мета дослідження полягає у розробці заходів щодо вдосконалення кредитної діяльності комерційного банку за рахунок використання сучасних методів економіко - математичних досліджень та математичного прогнозування економічних процесів. Методика дослідження. Використано елементи структурного аналізу, економіко-математичну формалізацію, метод коефіцієнтів, регресійне моделювання та лінійне програмування (LP, англ. Linear Programming) - метод досягнення найліпшого результату (найбільший прибуток або найменші збитки) у математичній моделі чиї вимоги представлені через лінійні відношення. Лінійне програмування $\epsilon$ особливим випадком математичного програмування (математичної оптимізаціі). Даний метод було використано 3 метою вирішення задачі оптимального розміру проценту банківського кредиту в рамках лінійного програмування 3 метою підвищення ефективності системи банківського кредитування. Результати дослідження. Пошук шляхів удосконалення кредитної діяльності банку в сучасних умовах слід починати з огляду минулого стану цісї проблеми. Загострення проблем у банківській діяльності виявилося в стрімкому зростанні обсягів прострочених кредитів великих банків. Перспективним напрямком удосконалення кредитнодепозитної політики є грамотне керування кредитною діяльністю. Основні вимоги, які повинні бути витримані - це обгрунтованість кредитної системи, тобто в будь-який момент повинна буди можливість розрахунку ймовірного прогнозу за допомогою сучасних математико-статистичних методів. При 
формуванні кредитно-депозитної політики банк повинен ураховувати основні напрямки вдосконалювання діяльності за рахунок програмних компонентів моделювання кредитної активності. Також обгрунтована можливість використання пакету задач лінійного програмування сумісно 3 пакетом Microsoft Excel з метою вирішення практичних задач визначення оптимальної величини ставки банківського кредиту. Наукова новизна. Наукова новизна отриманих результатів полягає у вирішенні ряду теоретичних та практичних проблем визначення величини ставки банківського кредиту, а саме: виявлені основні засади підвищення ефективності кредитної діяльності банку за рахунок використання сучасних математичних методів. Запропонована методика визначення величини ставки процента по кредиту за допомогою математичної моделі лінійного програмування реалізованої засобами Microsoft Excel (лінійне програмування). Практичне значення отриманих результатів. Запропоновані для впровадження результати дослідження можуть бути використані в кредитній діяльності банківської сфери національної економіки. Практичним ефектом є максимізація прибутку від раціонального визначення процента по кредиту.

Ключові слова: банк; кредит; ефективність кредитування; лінійне програмування; прогнозування; Microsoft Excel.

\section{УДК 336.71; JEL Classification: Q500}

Прокопенко Н.В. ИСПОЛЬЗОВАНИЕ ЭКОНОМИКОМАТЕМАТИЧЕСКИХ МЕТОДОВ ПРОГНОЗИРОВАНИЯ КАК ПУТЬ УСОВЕРШЕНСТВОВАНИЯ СИСТЕМЫ БАНКОВСКОГО КРЕДИТОВАНИЯ

Цель исследования заключается в разработке мероприятий относительно совершенствования кредитной деятельности коммерческого банка за счет использования современных методов экономико-математических исследований и математического прогнозирования экономических процессов. Методика исследования. Использованы элементы структурного анализа, экономикоматематическая формализация, метод коэффициентов, регрессионное моделирование и линейное программирование (LP, англ. Linear Programming) метод достижения наилучшего результата (наибольшая прибыль или наименьшие убытки) в математической модели, где требования представлены в виде линейных математических отношений. Линейное программирование является особым случаем математического программирования (математической оптимизации). Данный метод был использован с целью решения задачи оптимального размера процента банковского кредита в рамках линейного программирования с целью повышения эффективности системы банковского кредитования. Результаты исследования. Поиск путей усовершенствования кредитной деятельности банка в современных условиях следует начинать с обзора прошлого состояния этой проблемы. Обострение проблем в банковской деятельности проявилось в стремительном росте объемов просроченных кредитов крупных банков. Перспективным направлением усовершенствования 
кредитно-депозитной политики является грамотное управление кредитной деятельностью. Основные требования, которые обязательны к исполнению - это обоснованность кредитной системы, то есть в любой момент должна быть возможность расчета вероятного прогноза с помощью современных математико-статистических методов. При формировании кредитно-депозитной политики банк должен учитывать основные направления усовершенствования деятельности за счет программных компонентов моделирования кредитной активности. Также обоснована возможность использования пакета задач линейного программирования совместно с пакетом Microsoft Excel с целью решения практических задач определения оптимальной величины ставки банковского кредита. Научная новизна. Научная новизна полученных результатов заключается в решении ряда теоретических и практических проблем определения величины ставки банковского кредита, а именно: выявлены основные принципы повышения эффективности кредитной деятельности банка за счет использования современных математических методов. Предложена методика определения величины ставки процента по кредиту с помощью математической модели линейного программирования реализованной средствами Microsoft Excel (линейное программирование). Практическое значение полученных результатов. Предложенные для внедрения результаты исследования могут быть использованы в кредитной деятельности банковской сферы национальной экономики. Практическим эффектом является максимизация прибыли от рационального определения процента по кредиту.

Ключевые слова: банк; кредит; эффективность кредитования; линейное программирование; прогнозирование; Microsoft Excel.

\section{UDC 336.71; JEL Classification: Q500}

\section{Prokopenko M.V. USE OF ECONOMIC-MATHEMATICAL}

\section{FORECASTING METHODS AS A WAY TO IMPROVE THE BANK LENDING SYSTEM}

Purpose of the study is to develop measures to improve the lending activities of a commercial bank through the use of modern methods of economic, mathematical research and mathematical forecasting of economic processes. Methodology of research. The elements of structural analysis, economic and mathematical formalization, the method of coefficients, regression modeling and linear programming (LP, English Linear Programming) are used - a method for achieving the best result (the highest profit or the lowest losses) in a mathematical model, where the requirements are presented in the form of linear mathematical relations. Linear programming is a special case of mathematical programming (mathematical optimization). This method was used to solve the problem of the optimal size of the percentage of a bank loan in the framework of linear programming in order to improve the efficiency of the bank lending system. Findings. The search for ways to improve the bank's lending activities in modern conditions should begin with a review of the past state of this problem. The aggravation of problems in banking was 
manifested in the rapid growth in the volume of overdue loans from large banks. A promising direction for improving the credit and deposit policy is the competent management of credit activities. The main requirements that must be met are the validity of the credit system, that is, at any time it should be possible to calculate a probable forecast using modern mathematical and statistical methods. When forming a credit and deposit policy, a bank must take into account the main directions of improving its activities through software components for modeling credit activity. The possibility of using a package of linear programming problems in conjunction with the Microsoft Excel package in order to solve practical problems of determining the optimal value of the bank loan rate has also been substantiated. Originality. The scientific novelty of the results obtained lies in solving a number of theoretical and practical problems of determining the value of the bank loan rate, namely: the basic principles of increasing the efficiency of the bank's lending activities through the use of modern mathematical methods are revealed. A method is proposed for determining the value of the interest rate on a loan using a mathematical model of linear programming implemented using Microsoft Excel (linear programming). Practical value. The research results proposed for implementation can be used in lending activities of the banking sector of the national economy. The practical effect is to maximize profits from the rational determination of the interest on the loan.

Key words: bank; credit; lending efficiency; linear programming; forecasting; Microsoft Excel.

\section{Відомості про авторів / Сведения об авторах / About the Authors}

Прокопенко Микола Вікторович - Харківський національний автомобільно-дорожній університет, старший викладач кафедри економіки i підприємництва, м. Харків, Україна; e-mail: nvprokopenko@gmail.com; ORCID ID: https://orcid.org/0000-0002-4839-0154. Моб. 050-633-76-28.

Прокопенко Николай Викторович - Харьковский национальный автомобильно-дорожный университет, старший преподаватель кафедры экономики и предпринимательства, г. Харьков, Украина.

Prokopenko Nikolay - Kharkov National Automobile and Highway University, Senior Teacher at the Department of Economics and Entrepreneurship, Kharkiv, Ukraine. 